\title{
Environmental factors affecting the wintering raptor community in Armenia, Southern Caucasus
}

\author{
Gianpasquale Chiatante ${ }^{1,2}\left(\right.$ Michele Panuccio $^{2}$
}

Received: 2 August 2020 / Accepted: 5 January 2021 / Published online: 21 January 2021

(c) The Author(s) 2021

\begin{abstract}
The species-habitat relationships can change during the year because of the seasonality of resources. Therefore, the investigation of habitat use by animals in each season plays a fundamental role in their conservation. The main aim of this research was to investigate the raptor community that spends the winter in Armenia, southern Caucasus, and to explore its relationship with environmental features, such as land use and topography. During January 2012, we collected data by carrying out 15 roadside counts along which we calculated three community parameters: the relative abundance, the species richness, and the species diversity. Then, we carried out a multiple linear regression with the Information-Theoretic Approach, to explain the relationship between the parameters and environmental variables. Besides, we computed a Canonical Correspondence Analysis (CCA) between the species and the environment around their observations. As a general pattern, the community was associated with permanent crops, maybe because of their heterogeneity, which in turn allows them to support higher densities of prey during the winter. The most abundant species was the Black Kite (Milvus migrans), followed by the Common Kestrel (Falco tinnunculus) and the Griffon Vulture (Gyps fulvus). To our knowledge, this is one of the first studies investigating the wintering raptor community in the Caucasus, with raptors generally studied in this area during the breeding season and migration.
\end{abstract}

Keywords Birds of prey $\cdot$ Canonical Correspondence Analysis $\cdot$ Habitat use $\cdot$ Kilometric abundance index $\cdot$ Permanent crops

\section{Introduction}

Biodiversity preservation and restoration are the most important goals of conservation biology, and to apply adequate management schemes for the conservation of animals, the ecology and habits of each species should be known (Sinclair et al. 2006; Macdonald and Service 2007). Currently, the main variable used to understand and predict species distribution is habitat type (Guisan et al. 2017). The basis of

Supplementary material The online version of this article (https ://doi.org/10.1007/s42974-021-00038-7) contains supplementary material, which is available to authorized users.

Gianpasquale Chiatante

gp.chiatante@gmail.com

1 Department of Earth and Environmental Sciences, University of Pavia, Via Ferrata 1, 27100 Pavia, Italy

2 MEDRAPTORS (Mediterranean Raptor Migration Network), Via Mario Fioretti 18, 00152 Rome, Italy species-habitat relationships lies in habitat selection (Manly et al. 2002; Morrison et al. 2006), a process by which an individual must choose the habitats where it can live. These choices are influenced by a variety of constraints, such as the abundance and distribution of resources in both time and space, the distribution of conspecifics and predators, among others (Manly et al. 2002; Morrison et al. 2006). Species-habitat relationships are also intimately linked to the concept of the niche (Morrison et al. 2006). Hutchinson (1957) defined the niche as a hyper-volume in the multidimensional space of ecological variables, within which a species can maintain a viable population. In this view, niche dimensions are represented by multiple environmental gradients. A given species (or population) can exist in only a subset of the conditions defined by all the gradients (its potential or fundamental niche) but maybe further restricted in distribution (its realized niche) by predators and competitors. Indeed, in line with Gause principle (Gause 1934), stable populations of two species sharing the same niche cannot coexist in the same area; they must differ at least in one 
niche dimension (Amarasekare 2003). Species-habitat relationships can be investigated by habitat suitability models to define the potential response of a species to habitat availability, to produce predictive maps of its potential distribution, and to describe the characteristics of its niche (Guisan and Zimmermann 2000; Boyce et al. 2002; Chiatante 2019). Hence, this tool is very important for management purposes (Bayliss et al. 2005). Species-habitat relationships can change during the year because of the seasonality of resources (Manly et al. 2002; Morrison et al. 2006), and because many species change their distribution depending on the season, which sometimes involves migrations (Dingle 1996; Hansson and Åkesson 2014). In this case, the whole community change in a year more or less evidently and the species sometimes modify their requirements to coexist with others (Caula et al. 2008; Chen et al. 2011; Kwieciński et al. 2016; Yabuhara et al. 2019). Undoubtedly, birds are among the most mobile animals and their communities change seasonally (Rotenberry et al. 1979; Cody 1985), which involves some consequences. For example, during the breeding and non-breeding seasons migrants enrich the resident communities of birds, with consequent competition for space and food between them (Herrera 1978; Tellería and Pérez-Tris 2003; Wilson and Cresswell 2007). However, in some cases there is a positive interaction between species: in fact, the migrant can use the resident as a cue to assess habitat quality (Mönkkönen et al. 1999; Mönkkönen and Forsman 2002).

Habitat use of diurnal raptors has been poorly studied in winter, but they seem to be influenced mainly by food availability (Newton 1979) and, consequently, it is driven by their hunting strategies (Jankowiak et al. 2015b). Indeed, as for raptors, also prey species are spatially distributed in relation to their ecological requirements. Moreover, land use and the environmental structure affected the hunting success of raptors (Palatitz et al. 2015; Jaramillo et al. 2016) and prey availability is a primary element determining the size of their territories (Martínez-Hesterkamp et al. 2018). Despite the gap of knowledge, some researches give us some useful information for habitat use in winter by raptors. For example, Golden Eagle (Aquila chrysaetos) home ranges in winter were primarily composed of forest and open habitat (Miller et al. 2017), whereas Northern Goshawk (Accipiter gentilis) uses deciduous and conifer forests (Tornberg and Colpaert 2001). Prairie Falcons (Falco mexicanus), Ferruginous Hawks (Buteo regalis), and Rough-legged Buzzards (Buteo lagopus) inhabit natural grasslands of North America (Ingold 2010; Pandolfino et al. 2011), while Montagu's Harriers (Circus pygargus) were observed hunting in the savannah during the winter (Augiron et al. 2015). Yet, Bald Eagle (Haliaeetus leucocephalus) is positively associated with wetlands (Pandolfino et al. 2011), as well as Greater Spotted Eagle (Clanga clanga) (Pérez-García et al. 2014). In Europe, agricultural areas, especially the non-intensive, are used mainly by Common Buzzards (Buteo buteo) (Nikolov et al. 2006; Baltag et al. 2013; Panuccio et al. 2019a) and Common Kestrels (Falco tinnunculus) (Palomino Nantón 2011), which base their winter diet especially on voles (Żmihorski and Rejt 2007; Francksen et al. 2016). Particularly, Common Buzzards uses mainly permanent papilionaceous crops (e.g. lucerne, clover), cereal stubbles (including maize stubbles), and meadows (Wuczyński 2005). Likewise, American Kestrel (Falco sparverius), Northern Harrier (Circus hudsonianus), and White-tailed Kite (Elanus leucurus) occur in North American farmlands (Pandolfino et al. 2011). In general, both the diversity and abundance of raptors during the winter decrease when the proportion of urban areas is high (Palomino and Carrascal 2007; Jankowiak et al. 2015b; Panuccio et al. 2019b). In some cases, the adults spend the winter in their nesting territories occupying the same hunting ranges all the year, whereas in others they leave and disperse locally or on a long migration. These strategies may represent a progressive adaptation to decreasing availability of prey in winter (Newton 1979). However, some studies have pointed out that although preys are available, the wintering raptor density is limited by a shortage of perching and roosting sites, especially in open landscapes (Wuczyński 2005; Ingold 2010). Among raptors breeding in the Western Palearctic, 13 are trans-Saharan migrants that overwinter south of the Sahara, in the Sahel or tropical Africa, 17 have wintering grounds closed to their breeding territories, as the Mediterranean Basin and in western Asia, whereas 10 species winter partly in both regions (Newton 1979). This division may reflect dietary requirements, in as much as the species that remain in Europe and near the nesting territories have diets based on warm-blooded prey. This is in contrast with the long-distance migrant species that are insect-, reptiles-, and fish-eaters (Newton 1979; FergusonLees and Christie 2001). In addition, raptors may benefit from wintering close to their breeding grounds through a reduction in migratory costs, allowing an early arrival in the nesting territory, which in turn is positively correlated with the breeding success (Espie et al. 2000; Steenhof and Heath 2013; Paprocki et al. 2015).

This research aimed to investigate the relationships between the wintering raptor community and the environment (such as land use and topography) in the southern Caucasus, particularly in Armenia, in western Asia. Southern Caucasus holds a high species richness of raptors; indeed, 40 species have been recorded, including resident, breeding, wintering, migrating, and vagrant species (Abuladze 2013). Among the breeding species, Common Buzzards and Common Kestrel are the most widespread species, with up to 1000 and 5000 breeding pairs, respectively, followed by the Lesser Kestrel (Falco naumanni) and the Levant Sparrowhawk (Accipiter brevipes), which, however, are mainly localized in Azerbaijan (where 1500-3000 and 500-1000 
pairs breed, respectively) (BirdLife International 2015). Specifically, in Armenia the most abundant species is the Common Kestrel (250-400 pairs), followed by the Common Buzzard (100-150 pairs), the Eurasian Sparrowhawk (Accipiter nisus) (100-150), and the Lesser Kestrel (100-130 pairs) (BirdLife International 2015).

Moreover, Caucasus has special importance for migrating raptors because it is located on the crossroads between Europe and Asia and between breeding and wintering quarters of many species. The most important flyway is undoubtedly that of the Eastern Black Sea, with the Batumi bottleneck in Georgia (up to more than 1,000,000 individuals of 34 species) (Verhelst et al. 2011; Wehrmann et al. 2019). However, there are also other important flyways, such as the Mtkvari valley (up to 250,000 individuals of 26 species), Alazani (150,000-200,000 individuals of 24 species), and Javakheti (up to 200,000 individuals of 25 species) (Abuladze 2013). On the western Caspian coast, migrating raptors have mainly been studied along the shoreline of Dagestan (Russia) (Butiev et al. 1983; Kostin and Butiev 2000), even though these regions are known mainly for the migration of waders and other birds, especially at the Besh Barmag bottleneck in Azerbaijan (Shubin 1998; Heiss 2013; Heiss et al. 2020). On the other hand, during the winter 23 species occur, 18 of which are regular visitors and their number fluctuated between 4400 and 14,700 birds depending upon climatic conditions (Abuladze 2013). Generally, they inhabit areas with high prey availability and with no or little snow cover, up to $600 \mathrm{~m}$ above sea level and with heterogeneous landscapes. In Georgia, the most numerous species are by far the Black Kite (Milvus migrans), especially in the Kolkheti Lowland, with 3000-12,000 individuals, and the Hen Harrier (Circus cyaneus), with 600-1700 individuals (Abuladze 2013). Our study is important for at least two reasons. First, there are few studies related to wintering birds of prey in the Caucasus (Gavashelishvili et al. 2012; Abuladze 2013), despite the area hosting a fundamental route for raptor migration. Secondly, to the best of our knowledge, this is the first research concerning the wintering raptor community in Armenia, being the most research concerning the breeding community (Aghababyan 2006; Ananian 2009; Ananian et al. 2010, 2011).

\section{Materials and methods}

\section{Study area}

The study area was located on the southern slope of Caucasus $\left(44^{\circ} 17.10^{\prime} \mathrm{E}, 40^{\circ} 10.54^{\prime} \mathrm{N}\right)$, in particular in the provinces of Shirak, Aragatsotn, Armavir, Kotayk, Ararat, and in the municipality of Yerevan, in central-western Armenia (Fig. 1). The landscape is characterized by mountains with an average altitude of $1719 \mathrm{~m}$ a.s.l. (the highest peaks are Kakhamakhut at $2106 \mathrm{~m}$ a.s.l. and Mets Artenis at $2047 \mathrm{~m}$ a.s.1.). The climate is arid and continental with warm summers and cold winters, average annual precipitation of 200-600 mm, and an average annual temperature of $3-13{ }^{\circ} \mathrm{C}$. The land use is mainly characterized by pastures (59.8\%) and arable lands (20.7\%), followed by built-up areas (6.8\%) and forests/shrublands (4.2\%).

\section{Data collection}

Roadside surveys were carried out using the car transect method (Andersen et al. 1985; Millsap and LeFranc 1988; Viñuela 1997), by carrying out 15 transects at low speed $(20-40 \mathrm{~km} / \mathrm{h})$ once in January 2012, for an average length of $31.5 \mathrm{~km}$ each and a total of $466 \mathrm{~km}$. Transects were chosen to cover almost evenly the study area (Fig. 1). The perpendicular distance from the observer to each bird sighted was estimated to locate exactly its position. To do this, we required two measurements: (1) the distance between the observer and the bird and (2) the angle between the transect axis and the bird, which were taken with a rangefinder (Leica Rangemaster CRF 1600B, $7 \times 24$, error \pm 1 m; Leica, Solms, Germany) and a compass. Each observation was geolocalized using a Garmin Colorado 300 GPS (Garmin, Olathe, KS, USA). Other than relevant data (i.e. species, date/time, perpendicular distance from transect, coordinates of observation), we recorded also ancillary information on the bird, such as sex/age and behaviour. Birds flying over that had not taken off from or landed in the site were not included (Bibby et al. 2000). All counts were carried out on calm days with no precipitation.

\section{Environmental variables}

Land use was obtained by combining two heterogeneous datasets (Rosina et al. 2018). In particular, the land use map developed by Scientific Network for the Caucasus Mountain Region (SNC-mt) (Debarbieux et al. 2015; Adler et al. 2018) (available at http://sustainable-caucasus.unepgrid. $\mathrm{ch} /$ ) was updated by the vector layers (forests, human settlements, lakes and wetlands, and cliffs) provided by the Acopian Center for the Environment (ACE) (available at https://ace.aua.am/gis-and-remote-sensing/vector-data). The validation of the combined land cover map was based on the visual interpretation of high-resolution images on Google Earth (@ Google LLC; available at https://www.google.com/ earth/index.html) at 300 locations randomly selected in the study area (Dorais and Cardille 2011; Zhao et al. 2014). In this way, a more reliable map was obtained, with only $6.5 \%$ of misclassification. Geomorphological data were obtained from ALOS Global Digital Surface Model (@ JAXA) with 


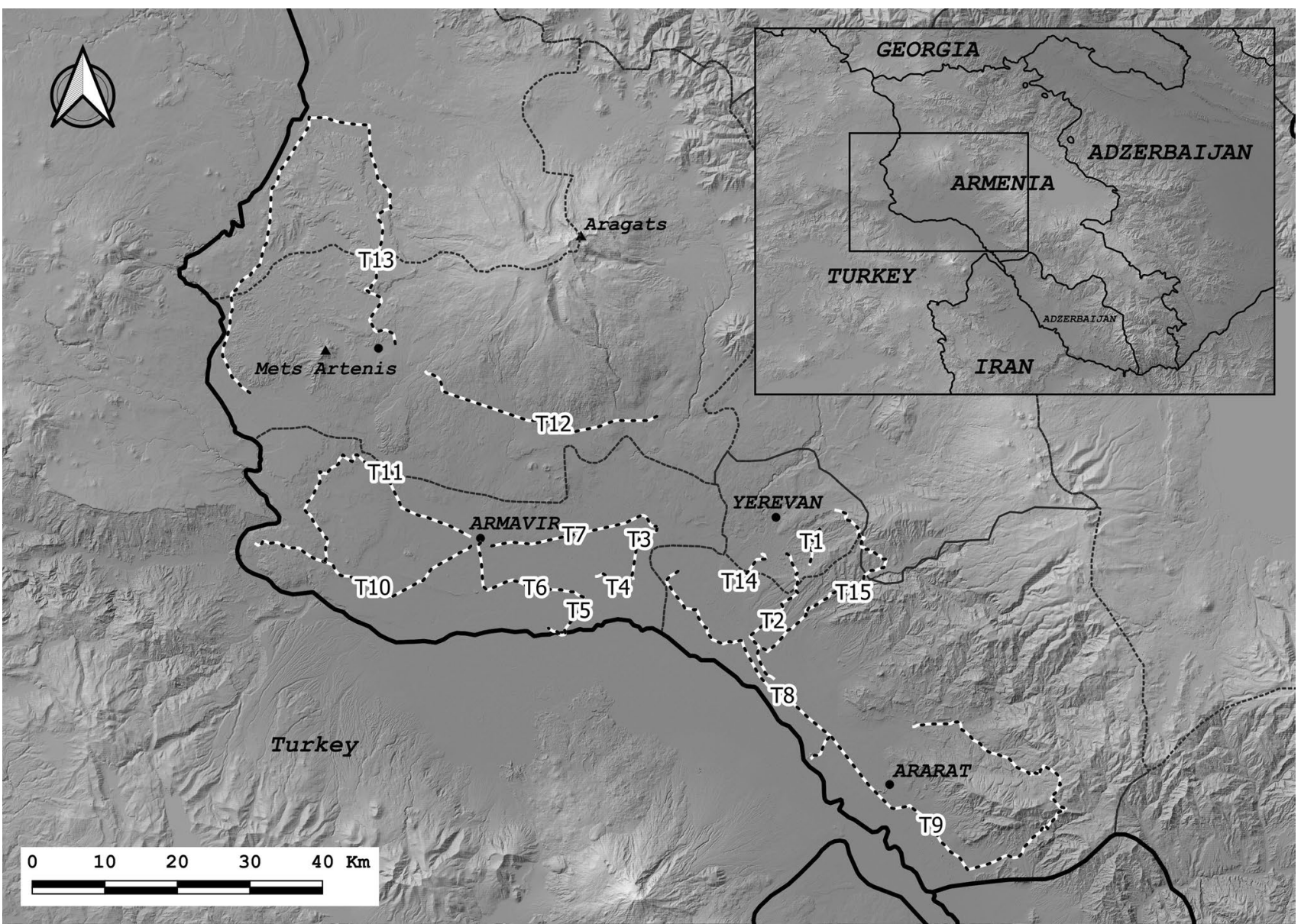

Fig. 1 Study area and the transects carried out to investigate the spatial distribution of wintering raptors in central-western Armenia during the winter of 2012

a spatial resolution of $30 \mathrm{~m}$. Spatial data were processed by the software Quantum GIS v.3.2.3 'Bonn'.

\section{Statistical analysis}

First, the relative abundances of both each species and all raptors were assessed along each transect by Kilometric Abundance Index (KAI), i.e. the number of birds observed per transect length. This simple but valuable relative measure has been used in many studies on raptors because abundances among transects can be compared easily (Carrete et al. 2009; Palomino Nantón 2011; Paz et al. 2013). Moreover, it is very appropriate for assessing bird abundances in open country, as in our study, because of the bias of roadside surveys in favour of open areas, grasslands, and arable lands (Millsap and LeFranc 1988; Harris and Haskell 2007). To assess the relationship between the community of raptors and the environment, the KAI of all raptors was related to seven environmental variables (Table 1), measured in a buffer of $500 \mathrm{~m}$ around transects, by multiple linear regression analysis (Legendre and Legendre 1998). We chose a
Table 1 Environmental variables used to investigate the spatial distribution of wintering raptors in Armenia

\begin{tabular}{lcc}
\hline Environmental variables & Mean \pm SE & Min-max \\
\hline Urban settlements (\% cover) & $19.6 \pm 4.50$ & $5.0-70.1$ \\
Arable lands (\% cover) & $24.7 \pm 6.56$ & $0.0-80.1$ \\
Permanent crops (\% cover) & $9.2 \pm 2.54$ & $0.0-27.0$ \\
Pastures (\% cover) & $43.8 \pm 6.75$ & $0.5-91.6$ \\
Lakes and reservoirs (\% cover) & $1.0 \pm 0.62$ & $0.0-9.2$ \\
Density of rivers (m/ha) & $34.9 \pm 7.54$ & $1.9-121.9$ \\
Mean altitude (m. a.s.1.) & $1025 \pm 56.61$ & $827-1589$ \\
\hline
\end{tabular}

The values were derived from the 500-m buffers around transects

buffer of $500 \mathrm{~m}$ because it was used in similar researches concerning wintering raptors (Ingold 2010; Pandolfino et al. 2011; Jankowiak et al. 2015b). Besides, both the species richness (calculated as the number of species observed along each transect) and the species diversity, quantified by the Shannon Diversity Index (Magurran and McGill 2011), were used as response variables. Then, a set of a priori models 
was built, for each model both $\mathrm{AIC}_{\mathrm{c}}$ and Akaike weights $\left(w_{i}\right)$ were calculated, and the models were ranked by the differences with minimum $\mathrm{AIC}_{\mathrm{c}}\left(\Delta \mathrm{AIC}_{\mathrm{c}}\right)$ (Burnham and Anderson 2002). Models with $\Delta \mathrm{AIC}_{\mathrm{c}} \leq 2$ were considered the best ones; therefore, they were used to compute model averaging; otherwise only the best model was selected for predictions and further analyses (Burnham and Anderson 2002). Finally, we measured the relative importance of variables $w$ by the sum of Akaike weights of the models in which each variable appeared (Burnham and Anderson 2002). For the analyses, all the considered variables were standardized by normalization, that is, each variable had a mean of zero and a standard deviation of one (Zuur et al. 2007). The Variance Inflation Factor (VIF) with a threshold of 3 was used to exclude the variables collinearity (Fox and Monette 1992; Zuur et al. 2010). The model's performance was tested through Pearson's correlation between observed and predicted values (Legendre and Legendre 1998). Moreover, the model's residuals were calculated and tested for normality by Kolmogorov-Smirnov test and spatial correlation by Moran $I$ test; the coefficient of determination $R^{2}$ was used as a measure of the variation explained by models (Zuur et al. 2007; Bivand et al. 2008).

Subsequently, a Canonical Correspondence Analysis (CCA) was carried out to examine the relationships between species and the percentage cover of land use in a circular buffer of $500 \mathrm{~m}$ around each observation. Canonical Correspondence Analysis is a multivariate constrained ordination technique, frequently used in ecology (Ter Braak 1986; Hill 1991; Guisan and Zimmermann 2000). To build the model and to test the significance of the variables, the ANOVA-like permutation test with 1000 replications was applied (Borcard et al. 2011; Kmecl and Denac 2018). To test for multivariate collinearity, the VIF was measured for the analysis with a threshold of 3 (Zuur et al. 2010). The spatial autocorrelation in residuals was tested with a geostatistical form of multi-scale ordination, which uses a variogram matrix to partition CCA results by distance (Wagner 2003, 2004; Couteron and Ollier 2005; Legendre and Gauthier 2014). In practice, this variogram plots the inertia profiles against distance and hence can be used to identify statistically uncorrelated patterns represented by the ordination axes (Wagner 2003, 2004; Couteron and Ollier 2005; Legendre and Gauthier 2014). Therefore, an empirical variogram of the inertia was calculated with distance classes of $1 \mathrm{~m}$, and a significance test for spatial autocorrelation of the residual inertia was performed for each distance class using a Mantel test with 1000 permutations (Wagner 2004; Borcard and Legendre 2012).

\section{Results}

During fieldwork, 168 raptors of 10 species were counted (Table 2). The Common Kestrel was the most widespread species, which was observed on 10 transects out of 15 ,
Table 2 Raptors observed in Armenia during the winter of 2012

\begin{tabular}{|c|c|c|c|c|c|c|c|c|c|c|c|c|c|}
\hline Species & $\mathrm{T} 2$ & T3 & $\mathrm{T} 4$ & T6 & $\mathrm{T} 7$ & $\mathrm{~T} 8$ & T9 & $\mathrm{T} 10$ & $\mathrm{~T} 11$ & $\mathrm{~T} 12$ & T13 & $\mathrm{T} 15$ & $\mathrm{KAI} \pm \mathrm{SE}$ \\
\hline $\begin{array}{l}\text { Cinereous Vulture } \\
\text { Aegypius monachus }\end{array}$ & - & - & - & - & - & 1 & - & - & - & - & - & 5 & $0.010 \pm 0.008$ \\
\hline $\begin{array}{l}\text { Griffon Vulture } \\
\text { Gyps fulvus }\end{array}$ & - & - & - & - & - & - & 1 & 5 & 12 & - & - & 3 & $0.034 \pm 0.020$ \\
\hline $\begin{array}{l}\text { Black Kite } \\
\text { Milvus migrans }\end{array}$ & - & 8 & 57 & - & - & 1 & - & - & - & - & - & - & $0.674 \pm 0.611$ \\
\hline $\begin{array}{l}\text { Western Marsh Harrier } \\
\text { Circus aeruginosus }\end{array}$ & - & 1 & 4 & - & - & - & 3 & - & - & - & - & - & $0.053 \pm 0.043$ \\
\hline $\begin{array}{l}\text { Hen Harrier } \\
\text { Circus cyaneus }\end{array}$ & - & - & 1 & - & - & - & - & - & 2 & - & 5 & - & $0.018 \pm 0.011$ \\
\hline $\begin{array}{l}\text { Common Buzzard } \\
\text { Buteo buteo }\end{array}$ & - & - & 1 & 2 & - & - & 2 & - & - & - & - & - & $0.019 \pm 0.012$ \\
\hline $\begin{array}{l}\text { Long-legged Buzzard } \\
\text { Buteo rufinus }\end{array}$ & - & - & 1 & - & - & - & 1 & - & - & - & - & - & $0.012 \pm 0.011$ \\
\hline $\begin{array}{l}\text { Eurasian Sparrowhawk } \\
\text { Accipiter nisus }\end{array}$ & 1 & - & 1 & - & - & 1 & 1 & - & - & - & - & - & $0.016 \pm 0.011$ \\
\hline $\begin{array}{l}\text { Northern Goshawk } \\
\text { Accipiter gentilis }\end{array}$ & - & - & - & - & - & - & & - & - & - & - & - & $0.001 \pm 0.001$ \\
\hline $\begin{array}{l}\text { Common Kestrel } \\
\text { Falco tinnunculus }\end{array}$ & 1 & 1 & - & 2 & 4 & 8 & 7 & 2 & 4 & 3 & 13 & 2 & $0.075 \pm 0.016$ \\
\hline Total & 2 & 10 & 65 & 4 & 4 & 11 & 16 & 7 & 18 & 3 & 18 & 10 & $0.361 \pm 0.687$ \\
\hline
\end{tabular}

For each species, the number of individuals is shown, as well as the average Kilometric Abundance Index (KAI). Transects (Ts) without observations (i.e. T1, T5, and T14) are not shown 
followed by Eurasian Sparrowhawk and Griffon Vulture, both detected on four transects. The average KAI showed that the Black Kite was the most abundant species, followed by the Common Kestrel and the Western Marsh Harrier (Table 2).

For the KAI, only one model entered in the best set of models $\left(w_{i}=0.93\right)$; therefore, we used only this for further analyses. The KAI of all raptors was positively associated with the cover of permanent crops and the mean altitude along transects (Tables 3, 4; Electronic Supplementary Materials, ESM Table S1; Fig. 2). There was no collinearity between selected variables (see Table 4) and predicted abundances were strongly correlated with observed values $(r=0.892, P<0.001)$. The residuals model were normally distributed $(D=0.135, P=0.948)$ and non-spatially correlated $(I=0.824, P=0.341)$; this model explained $75.4 \%$ of variance. For both species richness and diversity, three models had $\Delta \mathrm{AIC}_{\mathrm{c}} \leq 2$, including the null model. For the species richness, the sum of Akaike weights of the three best models was equal to 0.51 , whereas for the species diversity was equal to 0.50 . Based on these results, we assessed that for both these response variables, there was only weak evidence for the importance of environmental variables. However, similar to abundance, both the species richness and diversity seemed to have a positive relationship with the cover of permanent crops. Also, for species richness, the mean altitude along transects would appear to have a positive effect (Tables 3, 4; ESM Table S2-S3; Fig. 2). Contrarily, the density of rivers would seem to affect negatively species diversity (Table 4). There was no collinearity between selected variables (Table 4) and predicted values were significantly correlated with observed values (for the species richness, $r=0.553, P=0.049$; for the species diversity, $r=0.593, P=0.033$ ). Model residuals were normally distributed and non-spatially correlated both for the species richness $(D=0.251, P=0.330 ; I=-0.731, P=0.768)$ and the species diversity $(D=0.148, P=0.899 ; I=-0.407$, $P=0.658)$. The variance explained was comprised between 21 and $37 \%$ for the species richness, whereas it is between 18 and $21 \%$ for the species diversity.

The CCA showed how the 10 species fitted into the ordination space (Table 5, Fig. 3). The permutation test showed that both the global CCA model and the first axis explained a significant amount of variation in observed species
Table 3 Best set of models $\left(\Delta \mathrm{AIC}_{\mathrm{c}} \leq 2\right)$ explaining the occurrence of wintering raptors in Armenia
Table 4 Average models explaining the environmental requirements of wintering raptors in Armenia during the winter of 2012

\begin{tabular}{llrrrrrl}
\hline Response & Environmental variables & $d f$ & $\operatorname{logLik}$ & $\mathrm{AICc}$ & $\Delta$ AICc & $w_{i}$ & $R^{2}$ \\
\hline KAI & Altitude + permanent crops & 4 & 19.62 & -26.20 & \multicolumn{1}{c}{-} & 0.928 & 0.75 \\
Species richness & (Intercept) & 2 & -26.51 & 58.20 & 0.00 & 0.228 & - \\
& Permanent crops & 3 & -24.99 & 58.60 & 0.44 & 0.183 & 0.21 \\
& Altitude + permanent crops & 4 & -23.49 & 60.00 & 1.76 & 0.094 & 0.37 \\
Species diversity & (Intercept) & 2 & 1.61 & 2.00 & 0.00 & 0.200 & - \\
& Density of rivers & 3 & 3.13 & 2.40 & 0.43 & 0.162 & 0.18 \\
& Permanent crops & 3 & 2.93 & 2.80 & 0.82 & 0.133 & 0.21 \\
\hline
\end{tabular}

For each model, the degrees of freedom $(d f)$, the log-likelihood (logLik), the $\mathrm{AIC}_{\mathrm{c}}$ and the difference with the minimum $\mathrm{AIC}_{\mathrm{c}}\left(\Delta \mathrm{AIC}_{\mathrm{c}}\right)$, the Akaike weight $\left(w_{i}\right)$, and the coefficient of determination $R^{2}$ are shown

\begin{tabular}{|c|c|c|c|c|c|c|}
\hline Environmental variable & $\beta$ & SE & LCI & UCI & $w$ & VIF \\
\hline \multicolumn{7}{|c|}{ KAI (Kilometric Abundance Index) } \\
\hline Intercept & 0.159 & 0.017 & - & - & - & - \\
\hline Permanent crops (\%) & 0.125 & 0.020 & 0.080 & 0.170 & 1.00 & 1.312 \\
\hline Mean altitude (m a.s.1.) & 0.074 & 0.020 & 0.029 & 0.119 & 1.00 & 1.312 \\
\hline \multicolumn{7}{|l|}{ Species richness } \\
\hline Intercept & 2.077 & 0.572 & - & - & - & - \\
\hline Permanent crops (\%) & 1.031 & 0.635 & -0.213 & 2.275 & 0.55 & 1.087 \\
\hline Mean altitude (m a.s.1.) & 0.897 & 0.631 & -0.341 & 2.134 & 0.19 & 1.087 \\
\hline \multicolumn{7}{|c|}{ Species diversity (Shannon Index) } \\
\hline Intercept & 0.233 & 0.066 & - & - & - & - \\
\hline Permanent crops (\%) & 0.095 & 0.068 & -0.233 & 0.029 & 0.33 & - \\
\hline Density of rivers & -0.102 & 0.067 & -0.038 & 0.229 & 0.27 & - \\
\hline
\end{tabular}

The estimate $(\beta)$, the standard error (SE), the lower (LCI) and upper (UCI) 95\% confidence intervals, the relative importance of the variable $(w)$, and the Variance Inflation Factors (VIF) are shown. For species diversity, the VIF was not calculated because all models had only one variable 
Fig. 2 Response curves of the environmental variables related to the wintering raptors in Armenia during the winter of 2012
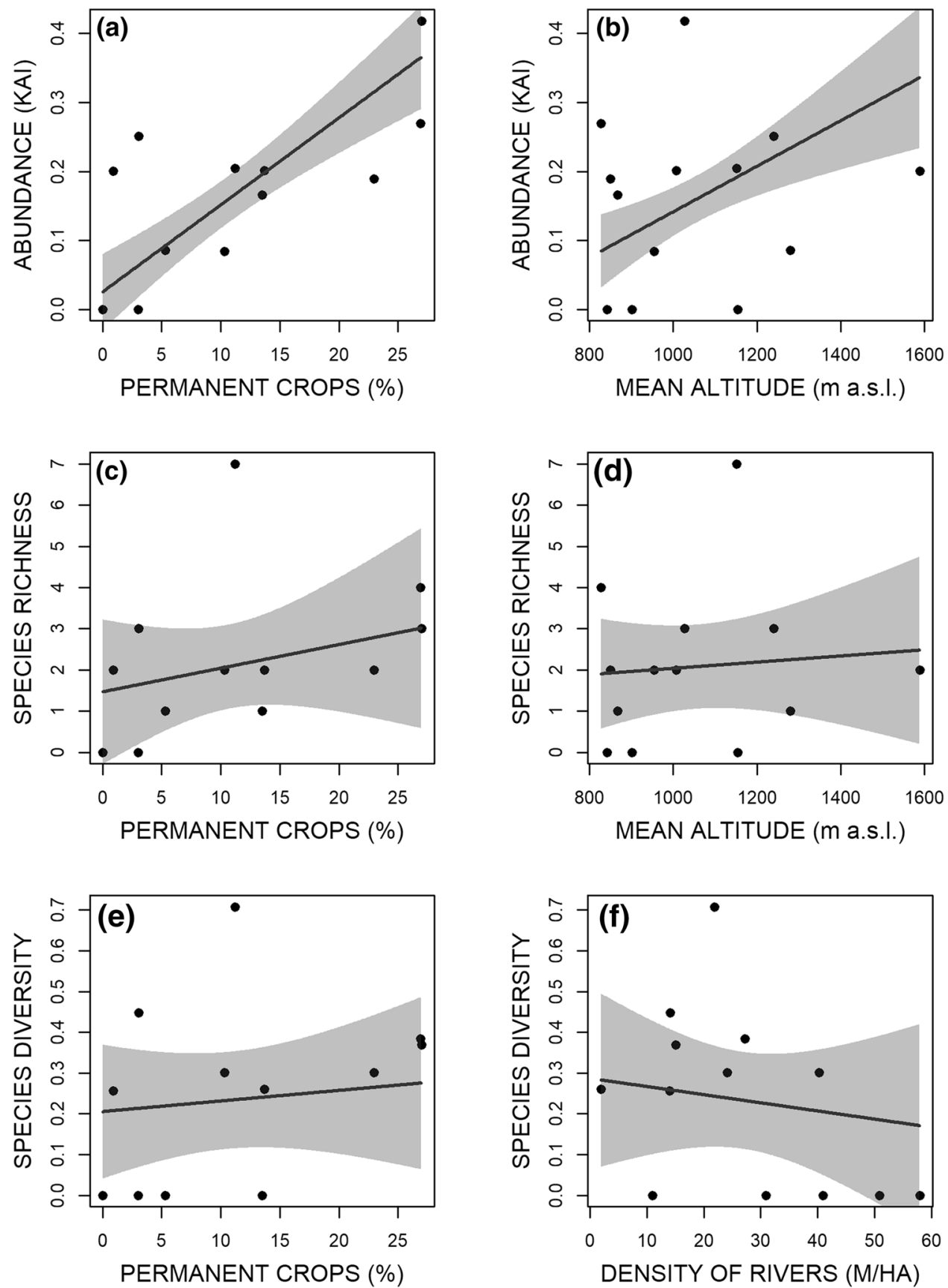

abundances (global model: $F=2.037, P=0.021$; CCA1: $F=6.515, P=0.009)$. Only the per cent cover of lakes and reservoirs contributed significantly to the observed variation in species abundances $(F=5.913, P=0.001)$. Cliffs and rocks $(F=1.093, P=0.288)$, permanent crops $(F=1.589$, $P=0.126)$, pastures $(F=0.537, P=0.847)$, and urban settlements $(F=1.053, P=0.316)$ were not significant. Of the total inertia (variance), only $11.4 \%$ was explained by the predictors and $64.0 \%$ of this value was explained by the first axis. This axis was positively correlated with lakes and reservoirs, whereas negatively with pastures and urban settlements. Relationships between species and environmental predictors could be discerned from the biplot (Fig. 3): the Western Marsh Harrier was associated with lakes and reservoirs, the Common Buzzard with permanent crops, and the Griffon Vulture with cliffs and rocks. A weak relationship existed between Black Kites and urban settlements. There was no collinearity between the environmental variables (VIF, urban settlements $=1.098$, permanent crops $=1.339$, pastures $=1.450$, lakes and reservoirs $=1.067$, cliffs and rocks $=1.077$ ). Arable land was removed from this analysis because it was correlated with pastures (Pearson's 
Table 5 Canonical Correspondence Analysis of the relationships between species and the percentage cover of land use in the 500-m buffer around the observations

\begin{tabular}{|c|c|c|c|c|c|}
\hline & Axis 1 & Axis 2 & Axis 3 & Axis 4 & Axis 5 \\
\hline Eigenvalue & 0.657 & 0.140 & 0.120 & 0.090 & 0.020 \\
\hline Proportion explained & 0.640 & 0.137 & 0.116 & 0.088 & 0.020 \\
\hline Cumulative proportion & 0.640 & 0.776 & 0.892 & 0.980 & 1.000 \\
\hline \multicolumn{6}{|l|}{ Permutation test } \\
\hline$F$-value $(P)$ & $6.515(0.009)$ & $1.391(0.805)$ & $1.184(0.824)$ & $0.894(0.794)$ & $0.202(0.995)$ \\
\hline \multicolumn{6}{|c|}{ Biplot scores for constraining variables } \\
\hline Urban settlements & -0.172 & -0.610 & -0.167 & 0.745 & 0.123 \\
\hline Permanent crops & 0.294 & 0.022 & -0.917 & -0.127 & 0.237 \\
\hline Pastures & -0.216 & -0.268 & 0.625 & -0.513 & 0.477 \\
\hline Lakes and reservoirs & 0.987 & -0.063 & 0.101 & 0.050 & 0.100 \\
\hline Cliffs and rocks & -0.074 & 0.771 & 0.034 & 0.463 & 0.430 \\
\hline \multicolumn{6}{|l|}{ Species scores } \\
\hline Cinereous Vulture (AEGMON) & -0.261 & -0.009 & -0.251 & -0.849 & 0.467 \\
\hline Griffon Vulture (GYPFULV) & -0.283 & 0.795 & 0.244 & 0.349 & 0.094 \\
\hline Black Kite (MILMIG) & -0.267 & -0.253 & 0.279 & -0.001 & -0.050 \\
\hline Western Marsh Harrier (CIRAER) & 3.201 & -0.103 & 0.110 & 0.128 & 0.153 \\
\hline Hen Harrier (CIRCYA) & 0.290 & 0.049 & 0.245 & -0.491 & 0.033 \\
\hline Common Buzzard (BUTBUT) & 1.901 & 0.190 & -0.273 & -0.054 & -0.371 \\
\hline Long-legged Buzzard (BUTRUF) & -0.292 & -0.128 & 0.272 & -0.136 & -0.134 \\
\hline Eurasian Sparrowhawk (ACCNIS) & -0.383 & -1.153 & -0.659 & 1.167 & 0.360 \\
\hline Northern Goshwak (ACCGEN) & -0.341 & -0.078 & 0.484 & -0.750 & 0.414 \\
\hline Common Kestrel (FALTIN) & -0.207 & 0.096 & -0.466 & -0.056 & -0.057 \\
\hline
\end{tabular}

correlation test, $r=-0.594, P<0.001)$ and generated multicollinearity $(\mathrm{VIF}>3)$. The variogram of the residual inertia showed no dependence on distances because the Mantel permutation test was never significant $\left(P_{\text {mean }}=0.549\right.$, $\left.P_{\text {min }}=0.100, P_{\max }=1.000\right)$.

\section{Discussion}

In this study, we provide first data on the wintering raptor community in Armenia and investigate the relationships between the environment and both the raptor community and each species during the winter in Armenia (southern Caucasus). Unfortunately, due to the sample size, we could not estimate species densities despite we collected data concerning the distances of observations. Indeed, these data could be used through some methods, such as distance sampling (Buckland et al. 1993), which use them to calculate the detectability of animals, which is very important to obtain more reliable densities estimation (Buckland et al. 1993; Buckland 2006; Marques et al. 2007). To reach the aim of this research, we used linear regression with model averaging and CCA, despite small sample sizes. The rule of thumb "one in ten" states that one predictive variable can be studied for every ten events while keeping the risk of overfitting low (Harrell et al. 1984, 1996; Peduzzi et al. 1996). Therefore, to reduce bias, we considered only models with a maximum of two predictors. However, for both species richness and diversity the null model was included in the best set of models, meaning that the uncertainty related to these response variables was not negligible. Therefore, the results concerning both the species richness and diversity should be taken with caution. Regarding CCA, Stevens (1986) found that weaker canonical correlations $(<0.30)$ require larger sample size $(n>200)$ to be detected, whereas stronger correlations $(>0.70)$ are evident also with smaller sample size $(n=50)$. Consequently, our results are reliable only for the Common Kestrel $(n=47)$ while for the other species they should be taken cautiously. Nonetheless, multivariate analysis is often exploratory or descriptive (Husson et al. 2010) and our results confirm general rules for habitat requirements of the species.

During the roadside census, we detected 10 species and calculated a relative abundance of 0.36 ind. $/ \mathrm{km}$. However, considering that we collected data only in 1 year and for a short time, we do not know if these data are representative of the typical winter season. Indeed, we found a species richness lower than that reported in nearby Georgia, where 18 species are regular winter visitors (Abuladze 2013). Unfortunately, we cannot make more comparisons with other 


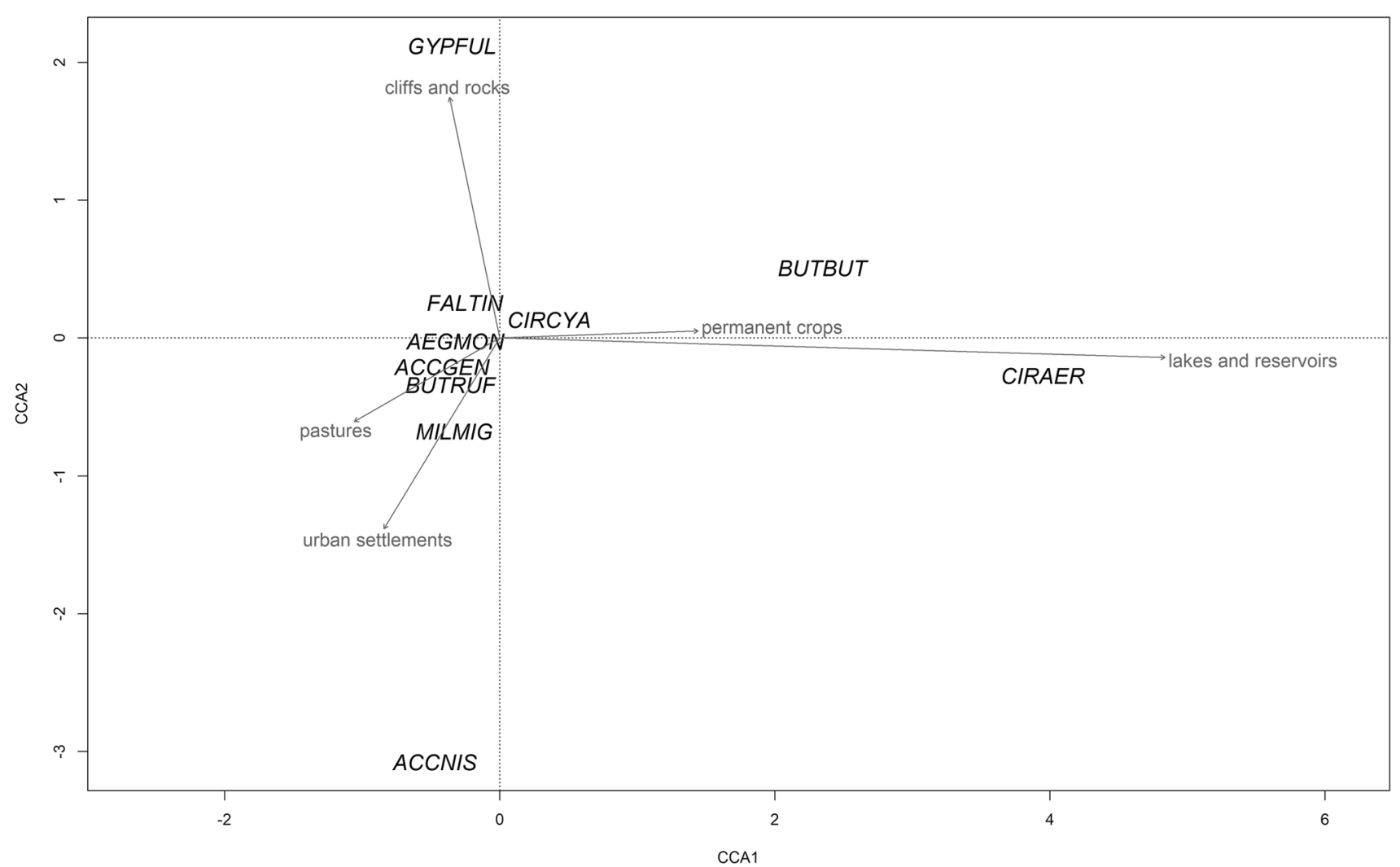

Fig. 3 Biplot of the Canonical Correspondence Analysis of the raptors wintering in Armenia during the winter of 2012 (species abbreviations: AEGMON Cinereous Vulture, GYPFUL Griffon Vulture, MILMIG Black Kite, CIRAER Western Marsh Harrier, CIRCYA

neighbouring regions because of the lack of other such studies in the Caucasus during the winter. However, there are many studies in Europe and the Mediterranean Basin, and the species richness found by us (equal to 10 species) is on average respect those reported in these studies (e.g. seven to 13 species; Meunier et al. 2000; Boano and Toffoli 2002; Lucia et al. 2011; Panuccio et al. 2019a, b). Regarding the abundance, it is slightly lower than those in Europe, where $0.45-0.97 \mathrm{ind} . / \mathrm{km}$ were observed during the winter (Boano and Toffoli 2002; Lucia et al. 2011; Panuccio et al. 2019a). However, our results are not surprising, because our study area was located at an average altitude of $1025 \mathrm{~m}$ a.s.l. and in Georgia wintering raptors usually are distributed up to $600 \mathrm{~m}$, even though solitary birds can be found up to $1700 \mathrm{~m}$ (Abuladze et al. 2011).

Our findings showed that wintering raptors, particularly their abundance, are positively associated with the permanent crops, which in Armenia are mainly composed of vineyards and orchards (e.g. of apricots Prunus armeniaca and peaches Prunus persica). In general, other studies demonstrated that in areas of intensive agriculture, orchards and vineyards were avoided by raptors (Swolgaard et al. 2008; Pandolfino et al. 2011), likely
Hen Harrier, BUTBUT Common Buzzard, BUTRUF Long-legged Buzzard, ACCNIS Eurasian Sparrowhawk, ACCGEN Northern Goshawk, FALTIN Common Kestrel)

because of the massive use of pesticides and rodenticides which are toxic to them through biomagnification in food chains (Merson et al. 1984; Blus et al. 1989; Elliott et al. 2005). However, nowadays the agricultural production in Armenia is still based on small farms (approximately $1.4 \mathrm{ha} /$ farms) and extensive management systems (Avetisyan 2010). This landscape configuration may be favourable to raptors due to the habitat complexity and the resulting high diversity of prey (Santamaría et al. 2019; Serafini et al. 2019). Indeed, as a general pattern, more complex raptor communities were found in areas showing higher environmental heterogeneity (Baltag et al. 2013; Jankowiak et al. 2015a; Panuccio et al. 2019a). The use of agricultural lands could occur also because overwintering conditions are more favourable in anthropogenic landscapes than in natural habitats, due to more stable food resources and less severe weather impacts (Gil and Brumm 2014). Indeed, usually, the abundance of wintering raptors is related to mild and snowless winters (Abuladze et al. 2011; Jankowiak et al. 2015b), even though some researchers found that lower temperatures were associated with higher numbers of observed raptors, at least for some species (e.g. Common Buzzard, Rough-legged Buzzard) 
(Wuczyński 2003; Kasprzykowski and Cieśluk 2011; Baltag et al. 2013). Among environmental variables, we evidenced a weak negative effect of the density of rivers on the diversity of wintering raptors. In general, this should be a positive relationship, especially in arid environments (Palmer and Bennett 2006; Seymour and Simmons 2008), but in our case there are few rivers which are mainly located far from permanent crops, explaining this result. Our results showed that the community is also related to the topography, as raptors were positively associated with altitude. Particularly, we found greater abundances up to 1000-1200 m a.s.l. Again, this agrees with past research in Georgia, which has shown that the upper altitudinal limit of wintering raptor distribution is $1000 \mathrm{~m}$ a.s.l. (Abuladze 2013). Among species, our results showed that the Black Kite was the most abundant raptor, as found in neighbouring Georgia (Abuladze 2013). Despite most Eurasian populations migrating to spend the winter in Africa south of Sahara (Ferguson-Lees and Christie 2001), this species regularly occurs during the winter also in the Middle East (Cramp and Simmons 1980; Ferguson-Lees and Christie 2001), and in the most recent decades also in the Mediterranean Basin, likely because of the climate warming (Sarà 2003; Panuccio et al. 2014; Literák et al. 2017). The analyses showed some association between the Black Kite and urban settlements, which is consistent with past researches in the Caucasus (Abuladze 2013) and with its general habits (Cramp and Simmons 1980; Ferguson-Lees and Christie 2001). Indeed, this species is positively associated with moderate levels of human population density, mainly due to its scavenging habits and hunting opportunism (Meunier et al. 2000; De Giacomo and Guerrieri 2008; Kumar et al. 2019). Following in abundance were the Common Kestrel and the Griffon Vulture. The first had an abundance of 0.08 ind./km, similar to abundances found in the Mediterranean Basin (0.02-0.10 ind./km; Boano and Toffoli 2002; Panuccio et al. 2019a, b). However, this species is generally uncommon during winter in the Caucasus, occurring only in small numbers (Abuladze 2013). There was no apparent association with a particular habitat type, which confirms the generalist habits of this raptor (Fargallo et al. 2009; Charter et al. 2011). Griffon Vulture was the third species most abundant. It was positively associated with the amount of cliffs and rocks, these being the main used habitat (Ferguson-Lees and Christie 2001; Gavashelishvili and McGrady 2006). However, the occupancy of cliffs also during the winter season could be related to its flight strategy. Indeed, Griffon Vultures often soar on thermals (Ferguson-Lees and Christie 2001) whose strength and regularity are positively related to the amount of sunlight and terrain ruggedness (Pennycuick 2008). Thus, the presence of cliffs, especially those that are south-facing, can produce regular thermal lifts, which ensure better flight conditions for the species (Gavashelishvili and McGrady 2006; Miller et al. 2017). Our analyses allow us to draw some conclusions about the habitat use also of other species. Unsurprisingly, the occurrence of Western Marsh Harrier is related to lakes and reservoirs, a rule for the species year-round (Cramp and Simmons 1980; Ferguson-Lees and Christie 2001), also in western Asia (Abuladze 2013; Al-Sheikhly and Al-Azawi 2019). Common Buzzards are mainly associated with permanent crops. Similarly, in Eastern Europe and Crete the species uses permanent crops (e.g. olive Olea europea groves) and other agricultural lands during the winter (Nikolov et al. 2006; Tzortzakaki et al. 2012; Baltag et al. 2013; Panuccio et al. 2019a), even if meadows are the main habitat type used for hunting in some places (Wuczyński 2005; Tapia et al. 2008; Wikar et al. 2008). Finally, the Eurasian Sparrowhawk is related to urban settlements. The use of built-up areas during winter, especially with large gardens and parks, is common for this species, which are favoured because of high prey density found in this environment in this season (Chamberlain et al. 2009; Schütz and Schulze 2018).

In conclusion, the wintering raptor community in Armenia at high altitude was poor and, as a general pattern, is related mainly to permanent crops, maybe because of their heterogeneity, which in turn support higher prey density during the winter. The most abundant species is the Black Kite, which regularly spends the winter in the Caucasus and is related to urban settlements, followed by the Common Kestrel and the Griffon Vulture. From a conservation perspective, if land use changes will happen in the next decades in Armenia, it should be kept in mind that the habitat heterogeneity could be the key to support a diversified community of raptors during the winter. However, nowadays the agricultural production in Armenia is still based on extensive management systems, even though in the next future plantations will be irrigated and mechanical pruning and harvest will occur, especially in vineyards (Avetisyan 2010). Anyway, some evidence shows that the irrigation of crops could be favourable for raptor conservation in low-intensity farming systems (Eisenman 1971; Ursúa et al. 2005), even if the intensive irrigation, as well as heavy intensification of agricultural practices in general, is detrimental also for these birds (Bird et al. 1996; Tella and Forero 2000; De Frutos et al. 2015).

Acknowledgements We thank Nicolantonio Agostini for his comments on an earlier draft of the manuscript. This article is dedicated to the memory of my colleague and beloved friend Michele Panuccio, who passed away before the preparation of the manuscript. 
Funding Open Access funding provided by Università degli Studi di Pavia. This research received no specific grant from any funding agency in the public, commercial, or not-for-profit sectors.

Availability of data and material The datasets generated during and/or analysed during the current study are available from the corresponding author on reasonable request.

\section{Compliance with ethical standards}

Conflict of interest The authors declare that there are no conflicts of interest.

Open Access This article is licensed under a Creative Commons Attribution 4.0 International License, which permits use, sharing, adaptation, distribution and reproduction in any medium or format, as long as you give appropriate credit to the original author(s) and the source, provide a link to the Creative Commons licence, and indicate if changes were made. The images or other third party material in this article are included in the article's Creative Commons licence, unless indicated otherwise in a credit line to the material. If material is not included in the article's Creative Commons licence and your intended use is not permitted by statutory regulation or exceeds the permitted use, you will need to obtain permission directly from the copyright holder. To view a copy of this licence, visit http://creativecommons.org/licenses/by/4.0/.

\section{References}

Abuladze, A. (2013). Birds of prey of Georgia (Vol. 6). Tbilisi: Lasha Khvichia.

Abuladze, A., Kandaurov, A., Edisherashvili, G., \& Eligulashvili, B. (2011). Wintering of raptors in Georgia: Results of long-term monitoring. In The birds of prey and owls of Caucasus. Tbilisi (AM): Ilia State University.

Adler, C., Palazzi, E., Kulonen, A., Balsiger, J., Colangeli, G., Cripe, D., et al. (2018). Monitoring mountains in a changing World: New horizons for the Global Network for Observations and Information on Mountain Environments (GEO-GNOME). Mountain Research and Development, 38, 265-269. https://doi. org/10.1659/MRD-JOURNAL-D-8-00065.1.

Aghababyan, K. E. (2006). Observations on breeding Peregrine Falcons (Falco peregrinus) in the Meghri District of Armenia. Falco, $28,4-6$.

Al-Sheikhly, O. F., \& Al-Azawi, A. J. (2019). The diurnal birds of prey (raptors) in the Mesopotamian marshes of southern Iraq with notes on their conservation status. Bulletin of the Iraq Natural History Museum, 15, 381-402. https://doi.org/10.26842/binhm 7.2019.15.4.0381

Amarasekare, P. (2003). Competitive coexistence in spatially structured environments: a synthesis. Ecology Letters, 6, 1109-1122.

Ananian, V. (2009). On the distribution and ecology of the Lesser Kestrel Falco naumanni in Armenia. Sandgrouse, 31, 44-54

Ananian, V., Aghababyan, K., Tumanyan, S., Janoyan, G., \& Bildstein, K. L. (2010). Shikra Accipiter badius breeding in Armenia. Sandgrouse, 32, 151-155.

Ananian, V., Aghababyan, K., Tumanyan, S., Janoyan, G., \& Bildstein, K. L. (2011). Levant Sparrowhawk Accipiter brevipes breeding populations in Yerevan and the Meghri region, Armenia. Sandgrouse, 33, 114-119.

Andersen, D. E., Rongstad, O. J., \& Mytton, W. R. (1985). Line transect analysis of raptor abundance along roads. Wildlife Society Bulletin, 13, 533-539.
Augiron, S., Gangloff, B., Brodier, S., Chevreux, F., Blanc, J.-F., Pilard, P., et al. (2015). Winter spatial distribution of threatened acridivorous avian predators: Implications for their conservation in a changing landscape. Journal of Arid Environments, 113, 145153. https://doi.org/10.1016/j.jaridenv.2014.10.001.

Avetisyan, S. (2010). Agriculture and food processing in Armenia. Yerevan (AM): Limush Publishing House.

Baltag, E. Ş., Pocora, V., Sfîcă, L., \& Bolboacă, L. E. (2013). Common Buzzard (Buteo buteo) population during winter season in NorthEastern Romania: the influences of density, habitat selection, and weather. Ornis Fennica, 90, 186-192.

Bayliss, J. L., Simonite, V., \& Thompson, S. (2005). The use of probabilistic habitat suitability models for biodiversity action planning. Agriculture, Ecosystems \& Environment, 108, 228-250. https:// doi.org/10.1016/j.agee.2005.02.008.

Bibby, C. J., Burgess, N. D., Hill, D. A., \& Mustoe, S. H. (2000). Bird census techniques (2nd ed.). London: Academic Press.

Bird, D. M., Varland, D. E., \& Negro, J. J. (1996). Raptors in human landscapes. Adaptations to built and cultivated environments. London: Academic Press.

BirdLife International. (2015). European red list of birds. Luxembourg: Office for Official Publications of the European Communities.

Bivand, R., Pebesma, E. J., \& Gómez-Rubio, V. (2008). Applied spatial data analysis with $R$. New York, NY: Springer.

Blus, L. J., Henny, C. J., \& Grove, R. A. (1989). Rise and fall of endrin usage in Washington State fruit orchards: Effects on wildlife. Environmental Pollution, 60, 331-349. https://doi. org/10.1016/0269-7491(89)90113-9.

Boano, G., \& Toffoli, R. (2002). A line transect survey of wintering raptors in the Western Po Plain on Northern Italy. Journal of Raptor Research, 36, 128-135.

Borcard, D., Gillet, F., \& Legendre, P. (2011). Numerical ecology with $R$. New York, NY: Springer.

Borcard, D., \& Legendre, P. (2012). Is the Mantel correlogram powerful enough to be useful in ecological analysis? A simulation study. Ecology, 93, 1473-1481. https://doi.org/10.1890/11-1737.1.

Boyce, M. S., Vernier, P. R., Nielsen, S. E., \& Schmiegelow, F. K. A. (2002). Evaluating resource selection functions. Ecological Modelling, 157, 281-300. https://doi.org/10.1016/S0304 $-3800(02) 00200-4$

Buckland, S. T. (2006). Point-transect surveys for songbirds: Robust methodologies. The Auk, 123, 345-357.

Buckland, S. T., Anderson, D. R., Burnham, K. P., \& Laake, J. L. (1993). Distance sampling: Estimating abundance of biological populations. London: Chapman \& Hall.

Burnham, K. P., \& Anderson, D. R. (2002). Model selection and multimodel inference: A practical information-theoretic approach (2nd ed.). New York, NY: Springer.

Butiev, V. T., Mikheev, A. V., \& Shubin, A. O. (1983). [Seasonal raptor migration along the western shore of the Caspian Sea]. In: V. M. Galushin (Ed.), Ecology of raptors: Proc. 1st Conf. On Ecology and Conservation of Raptors, Moskow, 16-18 February 1983. Nauka, Moskow, pp. 11-13.

Carrete, M., Tella, J. L., Blanco, G., \& Bertellotti, M. (2009). Effects of habitat degradation on the abundance, richness and diversity of raptors across Neotropical biomes. Biological Conservation, 142, 2002-2011. https://doi.org/10.1016/j.biocon.2009.02.012.

Caula, S., Marty, P., \& Martin, J.-L. (2008). Seasonal variation in species composition of an urban bird community in Mediterranean France. Landscape and Urban Planning, 87, 1-9. https://doi. org/10.1016/j.landurbplan.2008.03.006.

Chamberlain, D. E., Glue, D. E., \& Toms, M. P. (2009). Sparrowhawk Accipiter nisus presence and winter bird abundance. Journal of Ornithology, 150, 247-254. https://doi.org/10.1007/s1033 6-008-0344-4. 
Charter, M., Izhaki, I., \& Leshem, Y. (2011). Predation or facilitation? An experimental assessment of whether generalist predators affect the breeding success of passerines. Journal of Ornithology, 152, 533-539. https://doi.org/10.1007/s10336-010-0617-6.

Chen, Y., Ma, M., Li, W.-D., Hu, B.-W., \& Ding, P. (2011). Seasonal changes of bird communities in different habitats in desert region of Fukang, Xinjiang. Chinese Journal of Ecology, 30, 273-280.

Chiatante, G. (2019). Heterospecific social attraction in migrant birds: Habitat niche overlap between two threatened shrikes. Wildlife Research, 46, 25. https://doi.org/10.1071/WR18031.

Cody, M. L. (1985). Habitat selection in birds. Orlando, FL: Academic Press.

Couteron, P., \& Ollier, S. (2005). A generalized, variogram-based framework for multi-scale ordination. Ecology, 86, 828-834. https://doi.org/10.1890/03-3184.

Cramp, S., \& Simmons, K. E. L. (1980). Handbook of the birds of Europe, the Middle East and North Africa. Vol. II Hawks to Bustards. New York, NY: Oxford University Press.

De Frutos, A., Olea, P. P., \& Mateo-Tomás, P. (2015). Responses of medium- and large-sized bird diversity to irrigation in dry cereal agroecosystems across spatial scales. Agriculture, Ecosystems \& Environment, 207, 141-152. https://doi.org/10.1016/j. agee.2015.04.009.

De Giacomo, U., \& Guerrieri, G. (2008). The feeding behavior of the Black Kite (Milvus migrans) in the rubbish dump of Rome. Journal of Raptor Research, 42, 110-118. https://doi.org/10.3356/ JRR-07-09.1.

Debarbieux, B., Balsiger, J., Djordjevic, D., Gaberell, S., \& Rudaz, G. (2015). Scientific collectives in region-building processes (Reprint). Environmental Science \& Policy, 49, 21-31. https:// doi.org/10.1016/j.envsci.2015.02.007.

Dingle, H. (1996). Migration: The biology of life on the move. New York, NY: Oxford University Press.

Dorais, A., \& Cardille, J. (2011). Strategies for incorporating highresolution Google Earth databases to guide and validate classifications: Understanding deforestation in Borneo. Remote Sensing, 3, 1157-1176. https://doi.org/10.3390/rs3061157.

Eisenman, E. (1971). Range expansion and population increase in North and Middle America of the white-tailed kite (Elanus leucurus). American Birds, 25, 529-536.

Elliott, J. E., Miller, M. J., \& Wilson, L. K. (2005). Assessing breeding potential of peregrine falcons based on chlorinated hydrocarbon concentrations in prey. Environmental Pollution, 134, 353-361. https://doi.org/10.1016/j.envpol.2004.08.002.

Espie, R. H. M., Oliphant, L. W., James, P. C., Warkentin, I. G., \& Lieske, D. J. (2000). Age-dependent breeding performance in merlins (Falco columbarius). Ecology, 81, 3404-3415.

Fargallo, J. A., Martínez-Padilla, J., Viñuela, J., Blanco, G., Torre, I., Vergara, P., et al. (2009). Kestrel-prey dynamic in a Mediterranean region: The effect of generalist predation and climatic factors. PLoS ONE, 4, e4311. https://doi.org/10.1371/journ al.pone.0004311.

Ferguson-Lees, J., \& Christie, D. A. (2001). Raptors of the World. Boston, MA: Houghton Mifflin Harcourt.

Fox, J., \& Monette, G. (1992). Generalized collinearity diagnostics. Journal of American Statistical Association, 87, 178-183. https ://doi.org/10.2307/2290467.

Francksen, R. M., Whittingham, M. J., Ludwig, S. C., \& Baines, D. (2016). Winter diet of Common Buzzards Buteo buteo on a Scottish grouse moor. Bird Study, 63, 525-532. https://doi. org/10.1080/00063657.2016.1238868.

Gause, G. F. (1934). Experimental analysis of Vito Volterra's mathematical theory of the struggle for existence. Science, 79, 16-17.

Gavashelishvili, A., \& McGrady, M. J. (2006). Breeding site selection by bearded vulture (Gypaetus barbatus) and Eurasian griffon
(Gyps fulvus) in the Caucasus. Animal Conservation, 9, 159-170. https://doi.org/10.1111/j.1469-1795.2005.00017.x.

Gavashelishvili, A., McGrady, M., Ghasabian, M., \& Bildstein, K. L. (2012). Movements and habitat use by immature Cinereous Vultures (Aegypius monachus) from the Caucasus. Bird Study, 59, 449-462. https://doi.org/10.1080/00063657.2012.728194.

Gil, D., \& Brumm, H. (Eds.). (2014). Avian urban ecology: Behavioural and physiological adaptations (1st ed.). Oxford; New York: Oxford University Press.

Guisan, A., Thuiller, W., \& Zimmermann, N. E. (2017). Habitat suitability and distribution models: With applications in R. Cambridge: Cambridge University Press.

Guisan, A., \& Zimmermann, N. E. (2000). Predictive habitat distribution models in ecology. Ecological Modelling, 135, 147-186. https://doi.org/10.1016/S0304-3800(00)00354-9.

Hansson, L.-A., \& Akesson, S. (Eds.). (2014). Animal movement across scales (1st ed.). Oxford: Oxford University Press.

Harrell, F. E., Lee, K. L., Califf, R. M., Pryor, D. B., \& Rosati, R. A. (1984). Regression modelling strategies for improved prognostic prediction. Statistics in Medicine, 3, 143-152. https://doi. org/10.1002/sim.4780030207.

Harrell, F. E., Lee, K. L., \& Mark, D. B. (1996). Multivariable prognostic models: issues in developing models, evaluating assumptions and adequacy, and measuring and reducing errors. Statistics in Medicine, 15, 361-387. https://doi.org/10.1002/(SICI)10970258(19960229)15:4\%3c361:AID-SIM168\%3e3.0.CO;2-4.

Harris, J. B. C., \& Haskell, D. G. (2007). Land cover sampling biases associated with roadside bird surveys. Avian Conservation and Ecology, 2, 12. https://doi.org/10.5751/ACE-00201-020212.

Heiss, M. (2013). The importance of Besh Barmag bottleneck (Azerbaijan) for Eurasian migrant birds. Acta Ornithologica, 48, 151164. https://doi.org/10.3161/000164513X678900.

Heiss, M., Gauger, K., Himmel, C., Fetting, P., Haraldsson, T. A., Caucal, G., et al. (2020). The development of the Besh Barmag Bird Migration Count in Azerbaijan and its importance for the monitoring of Eurasian migrant birds. Sandgrouse, 42, 29-45.

Herrera, C. M. (1978). Ecological correlates of residence and nonresidence in a Mediterranean passerine bird community. Journal of Animal Ecology, 47, 871-890. https://doi.org/10.2307/3676.

Hill, M. O. (1991). Patterns of species distribution in Britain elucidated by canonical correspondence analysis. Journal of Biogeography, $18,247-255$.

Husson, F., Lê, S., \& Pagès, J. (2010). Exploratory multivariate analysis by example using $R$. Boca Raton, FL: CRC Press.

Hutchinson, G. E. (1957). A treatise on limnology. New York, NY: Wiley.

Ingold, D. J. (2010). Abundance and habitat use of winter raptors on a reclaimed surface mine in Southeastern Ohio. The Ohio Journal of Science, 110, 70-76.

Jankowiak, L., Antczak, M., Kwieciñski, Z., Szymañski, P., Tobolka, M., \& Tryjanowski, P. (2015a). Diurnal raptor community wintering in an extensively used farmland. Ornis Fennica, 92, 76-86.

Jankowiak, Ł., Polakowski, M., Kułakowski, T., Świętochowski, P., Tumiel, T., Broniszewska, M., et al. (2015b). Habitat and weather requirements of diurnal raptors wintering in river valleys. Biologia, 70, 1136-1142. https://doi.org/10.1515/biolog-2015-0117.

Jaramillo, M., Donaghy-Cannon, M., Vargas, F. H., \& Parker, P. G. (2016). The diet of the Galapagos Hawk (Buteo galapagoensis) before and after goat eradication. Journal of Raptor Research, 50, 33-44. https://doi.org/10.3356/rapt-50-01-33-44.1.

Kasprzykowski, Z., \& Cieśluk, P. (2011). Rough-legged Buzzard Buteo lagopus wintering in central eastern Poland: Population structure by age and sex, and the effect of weather conditions. Ornis Fennica, 88, 98-103.

Kmecl, P., \& Denac, K. (2018). The effects of forest succession and grazing intensity on bird diversity and the conservation value of a 
Northern Adriatic karstic landscape. Biodiversity and Conservation. https://doi.org/10.1007/s10531-018-1521-2.

Kostin, A. B., \& Butiev, V. T. (2000). Late spring migration of raptors at the western coast of the Caspian Sea. Russian Ornithology Journal, 89, 3-10.

Kumar, N., Gupta, U., Malhotra, H., Jhala, Y. V., Qureshi, Q., Gosler, A. G., et al. (2019). The population density of an urban raptor is inextricably tied to human cultural practices. Proceedings of the Royal Society B: Biological Sciences. https://doi.org/10.1098/ rspb.2018.2932.

Kwieciński, Z., Morelli, F., Antczak, M., Hromada, M., Szymański, P., Tobolka, M., et al. (2016). Seasonal changes in avian communities living in an extensively used farmland of Western Poland. European Journal of Ecology, 2, 9-18. https://doi.org/10.1515/ eje-2016-0012.

Legendre, P., \& Gauthier, O. (2014). Statistical methods for temporal and space-time analysis of community composition data. Proceedings of the Royal Society B: Biological Sciences, 281, 20132728. https://doi.org/10.1098/rspb.2013.2728.

Legendre, P., \& Legendre, L. (1998). Numerical ecology (2nd ed.). Amsterdam: Elsevier.

Literák, I., Horal, D., Alivizatos, H., \& Matušík, H. (2017). Common wintering of black kites (Milvus migrans migrans) in Greece, and new data on their wintering elsewhere in Europe. Slovak Raptor Journal, 11, 91-102. https://doi.org/10.1515/ srj-2017-0001.

Lucia, G., Panuccio, M., Agostini, N., \& Bogliani, G. (2011). A twoyear study of wintering raptors in Basilicata (southern Italy). In R. Tinarelli, A. Andreotti, N. Baccetti, L. Melega, F. Roscelli, L. Serra, \& M. Zenatello (Eds.), Atti XVI Convegno Italiano di Ornitologia. Presented at the XVI Convegno Italiano di Ornitologia, Scritti, Studi e Ricerche di Storia Naturale della Repubblica di San Marino, Cervia (IT).

Macdonald, D. W., \& Service, K. (Eds.). (2007). Key topics in conservation biology. Malden, MA: Blackwell Pub.

Magurran, A. E., \& McGill, B. J. (Eds.). (2011). Biological diversity: Frontiers in measurement and assessment. Oxford; New York: Oxford University Press.

Manly, B. F. J., McDonald, L. L., Thomas, D. L., Mcdonald, T. L., \& Erickson, W. P. (2002). Resource selection by animals: Statistical design and analysis for field studies (2nd ed.). Dordrecht: Kluwer Academic Publishers.

Marques, T. A., Thomas, L., Fancy, S. G., \& Buckland, S. T. (2007). Improving estimates of bird density using multiple-covariate distance sampling. The Auk, 124, 1229-1243.

Martínez-Hesterkamp, S., Rebollo, S., Kennedy, P. L., Pérez-Camacho, L., García-Salgado, G., \& Morales-Castilla, I. (2018). Territoriality in diurnal raptors: Relative roles of recent evolution, diet and nest site. Biological Journal of the Linnaean Society, 124, 126-137. https://doi.org/10.1093/biolinnean/bly020.

Merson, M. H., Byers, R. E., \& Kaukeinen, D. E. (1984). Residues of the rodenticide brodifacoum in voles and raptors after orchard treatment. Journal of Wildlife Management, 48, 212-216. https ://doi.org/10.2307/3808474

Meunier, F. D., Verheyden, C., \& Jouventin, P. (2000). Use of roadsides by diurnal raptors in agricultural landscapes. Biological Conservation, 92, 291-298. https://doi.org/10.1016/S0006 -3207(99)00094-4.

Miller, T. A., Brooks, R. P., Lanzone, M. J., Cooper, J., O’Malley, K., Brandes, D., et al. (2017). Summer and winter space use and home range characteristics of Golden Eagles (Aquila chrysaetos) in eastern North America. The Condor, 119, 697-719. https://doi. org/10.1650/CONDOR-16-154.1.

Millsap, B. A., \& LeFranc, M. N., Jr. (1988). Road transect counts for raptors: How reliable are they? Journal of Raptor Research, $22,8-16$.
Mönkkönen, M., \& Forsman, J. T. (2002). Heterospecific attraction among forest birds: A review. Ornithological Science, 1, 41-51. https://doi.org/10.2326/osj.1.41.

Mönkkönen, M., Härdling, R., Forsman, J. T., \& Tuomi, J. (1999). Evolution of heterospecific attraction: Using other species as cues in habitat selection. Evolutionary Ecology, 13, 93-104.

Morrison, M. L., Marcot, B. G., \& Mannan, R. W. (2006). Wildlifehabitat relationships: Concepts and applications (3rd ed.) Washington, DC: Island Press.

Newton, I. (1979). Population ecology of raptors. London: T \& AD Poyser.

Nikolov, S., Spasov, S., \& Kambourova, N. (2006). Density, number and habitat use of Common Buzzard (Buteo buteo) wintering in the lowlands of Bulgaria. Buteo, 15, 39-47.

Palatitz, P., Solt, S., Horváth, É., \& Kotymán, L. (2015). Hunting efficiency of Red-footed Falcons in different habitats. Ornis Hungarica, 23, 32-47. https://doi.org/10.1515/orhu-2015-0003.

Palmer, G. C., \& Bennett, A. F. (2006). Riparian zones provide for distinct bird assemblages in forest mosaics of south-east Australia. Biological Conservation, 130, 447-457. https://doi. org/10.1016/j.biocon.2006.01.006.

Palomino, D., \& Carrascal, L. M. (2007). Habitat associations of a raptor community in a mosaic landscape of Central Spain under urban development. Landscape and Urban Planning, 83, 268274. https://doi.org/10.1016/j.landurbplan.2007.04.011.

Palomino Nantón, D. (2011). Factors determining the large-scale seasonal abundance of the Common Kestrel in central Spain. Ardeola, 58, 87-101.

Pandolfino, E. R., Herzog, M. P., Hooper, S. L., \& Smith, Z. (2011). Winter habitat associations of diurnal raptors in California's Central Valley. Western Birds, 42, 62-84.

Panuccio, M., Agostini, N., Mellone, U., \& Bogliani, G. (2014). Circannual variation in movement patterns of the Black Kite (Milvus migrans migrans): A review. Ethology Ecology \& Evolution, 26, 1-18. https://doi.org/10.1080/03949370.2013.812147.

Panuccio, M., Agostini, N., Nelli, L., Andreou, G., \& Xirouchachis, S. (2019a). Factors shaping distribution and abundance of raptors wintering in two large Mediterranean islands. Community Ecology, 20, 93-103. https://doi.org/10.1556/168.2019.20.1.10.

Panuccio, M., Foschi, F., Todini, A., Baldi, A., Dominicis, N., De Filippis, P., et al. (2019b). Better to stay downtown or in the countryside? Raptors wintering in urban and rural Protected Areas of Rome (Central Italy). Avocetta, 43, 67-73. https://doi. org/10.30456/AVO.2019108.

Paprocki, N., Glennn, N. F., Atkinson, E. C., Strickler, K. M., Watson, C., \& Heath, J. A. (2015). Changing habitat use associated with distributional shifts of wintering raptors. Journal of Wildlife Management, 79, 402-412. https://doi.org/10.1002/jwmg.848.

Paz, A., Jareño, D., Arroyo, L., Viñuela, J., Arroyo, B., Mougeot, F., et al. (2013). Avian predators as a biological control system of common vole (Microtus arvalis) populations in north-western Spain: Experimental set-up and preliminary results. Pest Management Science, 69, 444-450. https://doi.org/10.1002/ps.3289.

Peduzzi, P., Concato, J., Kemper, E., Holford, T. R., \& Feinstein, A. R. (1996). A simulation study of the number of events per variable in logistic regression analysis. Journal of Clinical Epidemiology, 49, 1373-1379. https://doi.org/10.1016/S0895-4356(96)00236-3.

Pennycuick, C. J. (2008). Modelling the flying bird. Amsterdam: Academic Press.

Pérez-García, J. M., Sellis, U., \& Väli, Ü. (2014). Winter ranging behaviour of a greater spotted eagle (Aquila clanga) in southeast Spain during four consecutive years. Slovak Raptor Journal, 8, 123-128. https://doi.org/10.2478/srj-2014-0014.

Rosina, K., Batista e Silva, F., Vizcaino, P., Marín Herrera, M., Freire, S., \& Schiavina, M. (2018). Increasing the detail of European land use/cover data by combining heterogeneous data 
sets. The International Journal of Digital Earth. https://doi. org/10.1080/17538947.2018.1550119.

Rotenberry, J. T., Fitzner, R. E., \& Rickard, W. H. (1979). Seasonal variation in avian community structure: Differences in mechanisms regulating diversity. The Auk, 96, 499-505. https://doi. org/10.1093/auk/96.3.499.

Santamaría, A. E., Olea, P. P., Viñuela, J., \& García, J. T. (2019). Spatial and seasonal variation in occupation and abundance of common vole burrows in highly disturbed agricultural ecosystems. European Journal of Wildlife Research, 65, 52. https://doi. org/10.1007/s10344-019-1286-2.

Sarà, M. (2003). The colonization of Sicily by the Black Kite (Milvus migrans). Journal of Raptor Research, 37, 167-172.

Schütz, C., \& Schulze, C. H. (2018). Park size and prey density limit occurrence of Eurasian Sparrowhawks in urban parks during winter. Avian Research, 9, 30. https://doi.org/10.1186/s4065 7-018-0122-9.

Serafini, V. N., Priotto, J. W., \& Gomez, M. D. (2019). Effects of agroecosystem landscape complexity on small mammals: A multispecies approach at different spatial scales. Landscape Ecology, 34, 1117-1129. https://doi.org/10.1007/s10980-019-00825-8.

Seymour, C. L., \& Simmons, R. E. (2008). Can severely fragmented patches of riparian vegetation still be important for arid-land bird diversity? Journal of Arid Environments, 72, 2275-2281. https:// doi.org/10.1016/j.jaridenv.2008.07.014.

Shubin, A. O. (1998). The importance of the western Caspian coast for migrating and wintering waders. International Wader Study, 10, 403-412.

Sinclair, A. R. E., Fryxell, J. M., Caughley, G., \& Caughley, G. (2006). Wildlife ecology, conservation, and management (2nd ed.). Malden, MA; Oxford: Blackwell Publishing.

Steenhof, K., \& Heath, J. A. (2013). Local recruitment and natal dispersal distances in America kestrels. The Condor, 115, 584-592.

Stevens, J. (1986). Applied multivariate statistics for the social sciences. Mahwah, NJ: Lawrence Erlbaum Associate Inc.

Swolgaard, C. A., Reeves, K. A., \& Bell, D. A. (2008). Foraging by Swainson's Hawks in a vineyard-dominated landscape. Journal of Raptor Research, 42, 188-196. https://doi.org/10.3356/ JRR-07-15.1.

Tapia, L., Domínguez, J., \& Rodríguez, L. (2008). Hunting habitat preferences of raptors in a mountainous area (Northwestern Spain). Polish Journal of Ecology, 56, 323-333.

Tella, J. L., \& Forero, M. G. (2000). Farmland habitat selection of wintering lesser kestrels in a Spanish pseudosteppe: implications for conservation strategies. Biodiversity and Conservation, 9, 433-441. https://doi.org/10.1023/A:1008943116150.

Tellería, J. L., \& Pérez-Tris, J. (2003). Consequences of the settlement of migrant European Robins Erithacus rubecula in wintering habitats occupied by conspecific residents. Ibis, 146, 258-268. https://doi.org/10.1111/j.1474-919x.2003.00249.x.

Ter Braak, C. J. F. (1986). Canonical Correspondence Analysis: a new eigenvector technique for multivariate direct gradient analysis. Ecology, 67, 1167-1179.

Tornberg, R., \& Colpaert, A. (2001). Survival, ranging, habitat choice and diet of the Northern Goshawk Accipiter gentilis during winter in Northern Finland. Ibis, 143, 41-50.

Tzortzakaki, O., Simaiakis, S., \& Xirouchakis, S. (2012). Abundance of common buzzards (Buteo buteo) in olive monocultures in the island of Crete. Journal of Biological Research-Thessalon, 17, 44-50.

Ursúa, E., Serrano, D., \& Tella, J. L. (2005). Does land irrigation actually reduce foraging habitat for breeding lesser kestrels? The role of crop types. Biological Conservation, 122, 643-648. https:// doi.org/10.1016/j.biocon.2004.10.002.

Verhelst, B., Jansen, J., \& Vansteelant, W. (2011). South West Georgia: An important bottleneck for raptor migration during autumn. Ardea, 99, 137-146. https://doi.org/10.5253/078.099.0203.

Viñuela, J. (1997). Road transects as a large-scale census method for raptors: The case of the Red Kite Milvus milvus in Spain. Bird Study, 44, 155-165. https://doi.org/10.1080/000636597094610 51.

Wagner, H. H. (2003). Spatial covariance in plant communities: integrating ordination, variogram modeling, and variance testing. Ecology, 84, 1045-1057.

Wagner, H. H. (2004). Direct multi-scale ordination with canonical correspondence analysis. Ecology, 85, 342-351.

Wehrmann, J., de Boer, F., Benjumea, R., Cavaillès, S., Engelen, D., Jansen, J., et al. (2019). Batumi Raptor Count: Autumn raptor migration count data from the Batumi bottleneck, Republic of Georgia. ZooKeys, 836, 135-157. https://doi.org/10.3897/zooke ys.836.29252.

Wikar, D., Ciach, M., Bylicka, M., \& Bylicka, M. (2008). Changes in habitat use by the Common Buzzard (Buteo buteo L.) during non-breeding season in relation to winter conditions. Polish Journal of Ecology, 56, 119-125.

Wilson, J. M., \& Cresswell, W. R. (2007). Identification of potentially competing Afrotropical and Palaearctic bird species in the Sahel. Ostrich, 78, 363-368. https://doi.org/10.2989/OSTRI CH.2007.78.2.39.119.

Wuczyński, A. (2003). Abundance of Common Buzzard (Buteo buteo) in the Central European wintering ground in relation to the weather conditions and food supply. Buteo, 13, 11-20.

Wuczyński, A. (2005). Habitat use and hunting behaviour of Common Buzzards Buteo buteo wintering in south-western Poland. Acta Ornithologica, 40, 147-154.

Yabuhara, Y., Yamaura, Y., Akasaka, T., Yamanaka, S., \& Nakamura, F. (2019). Seasonal variation in patch and landscape effects on forest bird communities in a lowland fragmented landscape. Forest Ecology and Management. https://doi.org/10.1016/j.forec o.2019.01.030

Zhao, Y., Gong, P., Yu, L., Hu, L., Li, X., Li, C., et al. (2014). Towards a common validation sample set for global land-cover mapping. International Journal of Remote Sensing, 35, 4795-4814. https ://doi.org/10.1080/01431161.2014.930202.

Żmihorski, M., \& Rejt, Ł. (2007). Weather-dependent variation in the cold-season diet of urban Kestrels Falco tinnunculus. Acta Ornithologica, 42, 107-113. https://doi.org/10.3161/0001645077 81646861.

Zuur, A. F., Ieno, E. N., \& Elphick, C. S. (2010). A protocol for data exploration to avoid common statistical problems: Data exploration. Methods in Ecology and Evolution, 1, 3-14. https://doi. org/10.1111/j.2041-210X.2009.00001.x.

Zuur, A. F., Ieno, E. N., \& Smith, G. M. (2007). Analysing ecological data. New York, NY: Springer Science + Business Media, LLC. 